\title{
The Use of Scholarly Electronic Journals at the Indian Institute of Science: A Case Study in India
}

\author{
Dr. Golnessa Galyani Moghaddam \\ Assistant Professor, Dept. of Library and Information Science, University of \\ Shahed, Tehran, IRAN. E-mail: g_galyani@yahoo.com \\ Dr. V.G. Talawar \\ Professor, Dept. of Library and Information Science, University of Mysore, \\ Mysore, INDIA. E-mail: muvgt@yahoo.co.in
}

\begin{abstract}
:
The purpose of this paper is to investigate the use of scholarly electronic journals at the Indian Institute of Science. The paper examines the methodology and results from a questionnaire-based survey of networked electronic services in India at the Indian Institute of Science (IISc) libraries serving a variety of disciplines. A random sample of the main cohort was selected and during five months from January 2004 till May 2004, 700 copies of the questionnaire were distributed among forty departments of IISc; 397 completed and valid questionnaires (56.7 percent) were received. The results showed a growing interest in electronic journals among the users at the IISc. The electronic journals were mostly used for research needs and PDF format was the most preferred format. The fact that users have free access to electronic journals at all hours from their own computers seems to be the most appealing feature.
\end{abstract}

Keywords- Electronic Journal, Journal Usage, User Study, Indian Institute of Science

\section{Introduction}

Scholarly electronic journals are part of both scientific publishing and an emerging communications and publishing environment via the Internet. There are many factors that may affect the use of scholarly electronic journals. An attempt is made in this study to see how these resources are being used in a multi-disciplinary institute in India. It may be noted that "electronic journal" in this study refers to "scholarly electronic journals”.

\section{Literature Survey}

The user and usage studies of electronic journals appear in the literature in the late 1990s when a large number of electronic journals had become widely available. These studies were mostly carried out among the academic staff of institutes and colleges who were the most frequent users of scholarly journals (Diedrichs, 2001; Holmquist, 1997; Woodward, 1998; Lenares, 1999; Brown, 1999; Baldwin and Pullinger, 2000; Electronic Journals Survey, 2000; Wiley and Chrzastowski, 2002; Tenopir and King, 2002; Gargiulo, et. al, 2003; De Groote \& Dorsch, 2003; Bonthron, et al., 2003). 
In 1999, research was carried out at the Max Planck Society in Germany. The results of this survey showed a significantly high acceptance of electronic journals and an unwillingness to return to print versions only. Elsevier journals were most used, but the number of Elsevier electronic journals was also the highest offered by one publisher. The researchers also rated the advantages and disadvantages of electronic journals related to various aspects. The advantages include: the direct accessibility from the researchers' desktop, the downloading (or printing out) of articles directly, the currency and the up to date information, and full text retrieval possibilities. The disadvantages included: the lack of long term access and incomplete volumes, network dependency, reading from monitor, loss of certain attributes of the paper version, graphic quality, lack of citation status and standards. (Rusch-Feja and Siebeky, 1999). It may be noted that the advantages and disadvantages of electronic journals used in the present study are mostly extracted from the above study in Germany.

Another study at the Norris Medical Library at the University of Southern California compared the usage of a matched set of biomedical literature available to users both in print and on the web. During the six-month study period, there were approximately 28,000 electronic viewings of full- text articles from the study subset, compared to only 1,800 uses of the corresponding print volumes. The results further revealed a remarkably similar usage curve in the print and electronic data, with just 20 percent of titles accounting for nearly 60 percent of usage in both studies sets (Morse and Clintworth, 2000).

The librarians Clajus and Maier from the University and State Library in Köln carried out a survey among the academic staff and found that 16 percent of respondents did not want to renounce the print version of the journal under any circumstances. The biggest advantages of the new service were full-text access from their own desktop (49 percent), and the better currency of the electronic journal over print (Clajus and Maier, 2001).

Another usage study was conducted at the Stanford University in 2001 by interview. The project was conducted from November 2000 to March 2001 by researchers at the Institute for the Future. The result showed that the most significant current source of value from e-journals is in the scholars' ability to search them and online searching emphasizes the article as a relevant container of knowledge rather than the journal itself. In addition, there was not a single pattern of usage that predominated for e-journals and scholars used them for convenience (E-Journal Usage Study and Scholarly Practice, 2001).

A study by De Groote \& Dorsch at the University of Illinois reported that print journal usage decreased significantly since the introduction of online journals. This decrease occurred regardless of whether a journal was available only in print or both online and in print. Interlibrary loan requests also significantly decreased since the introduction of online journals. The decrease in use of the print collection suggests that many patrons prefer to access journals online (De Groote \& Dorsch, 2001).

In 2002, another user study was carried out of scientists at the Rudjer Boskovic Institute (RBI) in Zagreb. The results showed a high acceptance and use of electronic journals. The RBI respondents stressed the availability before the print version as the most important advantage of the electronic journals, and as the most important disadvantage the slow download. Very few respondents thought that electronic journals have no disadvantages at all. Most of the respondents preferred print version 
in the situation where both versions were available, but many used both versions equally (32 percent and 33 percent) (Pazur, 2002).

A study by Obst (2003) showed that print journal usage decreased by 22.3 in the first year and 30.2 percent in the second after the introduction of online journals. Journals published both in print and online lost 30.4 percent of their print usage within 2 years. Two clearly distinguishable groupings emerged: while with Academic Press and Elsevier, e-journal usage exceeded print usage by a factor of 3 or 4, the ejournals of Blackwell, HighWire and Springer were used on average 14.6 times as frequently as the corresponding print journals. Print titles not available online suffered a greater decline in usage compared with print/online journals (Obst, 2003).

In 2004 in the UK, a project designed to test a hypothesis that learning can be enhanced by promoting the use of e-journals was conducted by the Business School at University College Worcester (UCW). Analysis of the results indicated that effective collaboration between academic and library staff, the timely embedding of ejournals into the learning process and associating it with the assessment process, can significantly enhance the learning of students. The data indicated an encouraging increase in journal usage for assignment research (Colvin and Keene, 2004).

The results of a study at the University of Tennessee Health Science Center showed that the medical faculty read a great deal, especially compared to scientists. The most frequently reported purpose of reading is to support their primary research (30 percent of reading). The majority of reading came from recently published articles and mostly from personal subscriptions. The medical faculty continues to rely on print journals (approximately 70 percent of readings) versus electronic journals. Medical faculty read more articles than others and needed information digested and verified to save them time. Convenience and currency were highly valued attributes (Tenopir, King \& Bush, 2004).

Literature studies show that in many studies researchers made a comparison between print and electronic journals usage, however, the present study investigates the use of electronic only journals which are available in a particular institute.

The research studies described in the paper also demonstrate that the use of electronic journals has increased steadily since 1996 and they have been accepted well among users. The present study attempts to discover the acceptance of electronic journals in an Indian institution.

It is interesting to note that the reading pattern of journals is changing. Tenopir and King have done many studies on the reading pattern of scholarly journals and published many papers and a substantial book. They believe that while evidence suggests that amount of reading and time spent reading have been relatively stable over the past 20 years, there have been some changes in the ways in which scientists identify the articles they read and there are appreciable differences in the sources of these articles (Tenopir and King, 2000). Previous studies of scientists' reading habits had found that scientists in all disciplines read and value peer reviewed journal articles, but there are considerable differences in the amount that they read and whether they prefer print or electronic sources (Kling and McKim, 1997). Physicists, for example, are high end users of eprint services, and read more articles per year on average than engineers, but fewer than chemists. Medical faculty with $\mathrm{PhD}$ degrees prefer electronic sources on the average more often than medical faculty with M.D. 
degrees. Scientists who work in academia generally read more than those in corporations or government laboratories (Tenopir, King and Bush, 2002).

Tenopir points out "My research on faculty reading patterns with Donald W. King shows that medical faculty read two to three times as many journal articles on average than humanities or engineering faculty and a bit more than science or social science faculty. These measures of reading have held true over three decades, indicating that they relate to the nature of research in each discipline, not to the value of the reading by faculty. Humanities faculty relies on other sources such as books and primary materials, so while each journal reading may be valuable, there will not be as many. Engineers read many specifications and reports in addition to journal articles", (Tenopir, 2005).

A recent study by Liu showed that a screen-based reading behavior is emerging for reading electronic documents. The screen-based reading behavior is characterized by more time spent on browsing and scanning, keyword spotting, one-time reading, nonlinear reading, and reading more selectively, while less time is spent on in-depth reading, and concentrated reading. Annotating and highlighting while reading is a common activity in the printed environment. However, this "traditional" pattern has not yet migrated to the digital environment when people read electronic documents (Liu, 2005). The reading patterns of electronic journals are considered in the present study, although are not the only focus.

Earlier studies on reading behavior (such as Brown, 1999; Woodward, 1998) had shown that the users prefer print media for reading over electronic, while recent studies reflect an acceptance of reading on monitor (such as Liu, 2005). The preference of print and electronic media is also studied in the present survey at IISc.

It may be noted that although the review of literature shows an increase of use in electronic journals along with a decrease in use of print collections; more recent studies reveal an increase in the usage of older material is occurring as the result of increased visibility/accessibility of older material in the digital environment (Nicholas et al., 2005; Odlyzko, 2000). The Nicholas study is done by using transaction log analysis which is a recent method to trace journals usage in the digital environment. Deep Log Analysis (DLA) is a methodology developed by the Centre for Information Behaviour and the Evaluation of Research (CIBER) team at UCL (University College London). A recent study using deep log analysis showed that for different kinds of articles viewed, people who just viewed a table of contents page were far more likely to be current awareness "checkers," as nearly half their views related to the current period, while those who viewed a journal issue and also went on to view an article or abstract were more likely to view older articles (Huntington, et al, 2006).

Finally, there were many similar results in the studies reviewed in this paper, however, we should keep in mind that differences in the direction of effects between different studies can be attributed to the different sampling methods, or to the methodology.

\section{Objective of the Study}

The study is carried out to see how scholarly electronic journals are being used at a multi-disciplinary institute in India. It aimed to identify the users' opinions of different features of electronic journals, their awareness of electronic journals service, 
use of different publishers, purpose of use, components of use, preferred formats and more.

\section{Methodology}

In usage surveys, data are often obtained by using questionnaires. It may be noted that there are basically four methods of data gathering for profiling electronic journals use including questionnaire, interview, transaction log and citation study. Each method has its unique strengths and weaknesses. Transaction log is a computer-aided method of data gathering in the usage studies of electronic journals. Data are often obtained by using a questionnaire; these data are standardized, for easy comparison. Data gathering by questionnaire is a popular method and it is easily understood. However, much time has to be spent in designing and piloting the questionnaire. Analysis of the results, even with the aid of an appropriate computer package, is also time-consuming. The questionnaire method was used for the collection of usage data in the present study. The respondents for the questionnaire have been drawn from the Indian Institute of Science (IISc) located in Bangalore, India. Major parameters for choosing IISc are:

1. Access to significant number of electronic journals from distinguished publishers

2. Multi-disciplinary institute providing coverage of different subjects areas

3. Significant number of users of electronic journals

IISc is an institute of higher learning and is one of the oldest centers of its kind in India, and has a high international standing in the academic world. Internet facilities are available in all departments and researchers have 24 hours access to 6000 electronic journals. There are few institutions in India which have access to significant numbers of scholarly electronic journals. Keeping in view the objective of collecting usage data from different disciplines/subjects areas, the study distributed questionnaires to the faculty and students of all Departments at the IISc in two stages:

\section{A pilot study \\ 2. The full study}

The pilot study distributed 50 copies of the questionnaire to 12 departments of IISc in November 2003. This helped to design the questionnaire for the full fledged study. . This initial study helped to identify the major publishers whose journals were actually being used at IISc. The pilot study also helped to eliminate ambiguity of some questions and fine tune the questionnaire.

A sample for the main study was selected at random from January to May 2004. 500 copies of the questionnaire were distributed on different days among 40 departments of IISc. Users used to go to the central library of IISc namely J.R.D TATA Memorial Library in order to use library resources. Therefore, 200 more questionnaires were also distributed randomly to users at the J.R.D TATA Memorial Library during the same period. This made it possible to generalize the result of the study to the entire IISc.

A total of 397 completed and valid questionnaires (56.7 percent) were received. The total staff and students comprise 450 Academic Staff, 1215 Research Staff and 480 Post Graduate Students as well as an unknown number of guest users who 
comprised 18 percent of the sample. Table I shows the response rates from the groups of users at the IISc.

\begin{tabular}{|c|l|c|c|}
\hline SN & \multicolumn{1}{|c|}{ Status of Respondents } & $\begin{array}{c}\text { Number of } \\
\text { Response }\end{array}$ & Percentage \\
\hline 1 & Research Students (M.Phil, Ph.D) & 210 & 52.89 \\
\hline 2 & Postgraduate Students (M.Sc, ME, M.B.A, MA) & 94 & 23.67 \\
\hline 3 & Guest Users & 55 & 13.85 \\
\hline 4 & Research Staff & 28 & 7.05 \\
\hline 5 & Academic Staff & 10 & 2.51 \\
\hline- & Total & 397 & 100 \\
\hline \hline
\end{tabular}

Table I: Ranked Number of Responses by Status of Users at the IISc

The Principal Component Analysis (PCA) was used for statistical data analysis. The PCA is a statistical data analysis technique used to reduce the dimensionality of multivariate data. According to Smith "PCA reduces data dimensionality by performing a covariance analysis between factors. Covariance is always measured between two factors. So with three factors, covariance is measured between factor $x$ and $y ; y$ and $z$, and $x$ and $z$. When more than 2 factors are involved, covariance values can be placed into a matrix" (Smith, 2002).

When the analysis finishes, the Principal Components Analysis window appears, displaying each component as a line in graph mode. The significance of each component is represented by the color of its graph line, as defined by the color bar. After PCA analysis, the browser displays a scores plot in which the first and second principal components (representing the largest fraction of the overall variability) are plotted on the vertical and horizontal axis respectively. Components that exhibit high levels of the first principal component and low levels of the second principal component are displayed in the lower right corner of the plot, and components exhibiting equal levels of the two components lie along the diagonal.

\section{Data Analysis}

\section{Awareness of Electronic Journal Service}

In response to the first question "Are you aware of the availability of electronic/online journals at your institute?” 97.7 percent (388 out of 397) responded positively and 2.2 percent negatively (9 out of 397).The 9 respondents did not answer the remaining questions. So, analysis of usage was carried out on the 388 remaining questionnaires. 


\section{Use of Publishers}

The users were asked about use of different publishers. The data regarding preference of the publishers of electronic journals is summarized and ranked in Table II based on the percentage of use at IISc.

\begin{tabular}{|c|c|c|c|}
\hline SN & Name of Publishers & Yes & Percentage \\
\hline 1 & Elsevier (Included Academic Press) & 254 & 63.97 \\
\hline 2 & John Wiley \& Sons, Inc. & 151 & 38.03 \\
\hline 3 & Springer-Verlag & 138 & 34.76 \\
\hline 4 & $\begin{array}{l}\text { IEEE (Institute of Electric and Electronic } \\
\text { Engineering) }\end{array}$ & 119 & 29.97 \\
\hline 5 & American Chemical Society & 93 & 23.42 \\
\hline 6 & Cambridge University Press & 67 & 16.87 \\
\hline 7 & Kluwer Academic Publishing & 61 & 15.36 \\
\hline 8 & Oxford University Press & 60 & 15.11 \\
\hline 9 & AIP (American Institute of Physics) & 56 & 14.1 \\
\hline 10 & APS (American Physical Society) & 54 & 13.6 \\
\hline 11 & $\begin{array}{l}\text { ACM Press (American Computing and } \\
\text { Machinery Press) }\end{array}$ & 50 & 12.59 \\
\hline 12 & IOP (Institute Of Physics) (UK) & 41 & 10.32 \\
\hline 13 & Blackwell Publishing & 39 & 9.82 \\
\hline 14 & MIT Press & 39 & 9.82 \\
\hline 15 & ASCE (American Society of Civil Engg.) & 25 & 6.29 \\
\hline 16 & American Society for Microbiology & 24 & 6.04 \\
\hline 17 & Taylor \& Francis, Group & 23 & 5.79 \\
\hline 18 & $\begin{array}{l}\text { ASBMB (American Society for Biochemistry } \\
\text { and Molecular Biology) }\end{array}$ & 15 & 3.77 \\
\hline 19 & MCB University Press (Emerald) & 12 & 3.02 \\
\hline 20 & Sage Publication & 10 & 2.51 \\
\hline
\end{tabular}

Table II: Ranked List of Publishers by Use at IISc 
Electronic journals from Elsevier are being used most by the IISc respondents with 63.9 percent of the total usage and Sage Publication recorded the lowest usage rate with mere 2.5 percent. The literature study also showed that Elsevier journals were most used at the Max Planck Society in German (Rusch-Feja and Siebeky, 1999).

It is not surprising that the largest publisher of electronic journal - i.e., Elsevier with 1,349 journals, as opposed to 436 from Springer-Verlag, 300 from John Wiley \& Sons and 120 from IEEE - was found to be most preferred publisher in this study. It should also be noted that Academic Press merged with Elsevier in January 2003. Elsevier topping the list is expected in view of its dominant position both in terms of absolute number of journals, as well as the broad coverage of subject areas which reflected the concerns of researchers in this study.

\section{Purpose of Use}

The opinion of different categories of respondents - namely faculty, research staff, research scholars and students - with regard to the use of electronic journals were collected on a five point scale. PCA was also carried out on the data in order to obtain a clear idea of the order of preference of use purposes. By comparing the Scores Plot and the Correlation Loading Plot, it is clear that the electronic journals are most used for 'Research Needs', often used for 'Education', sometimes used for 'Current facts and services' and least used for 'Recreational' and 'Win Award' (See Figure 1). 


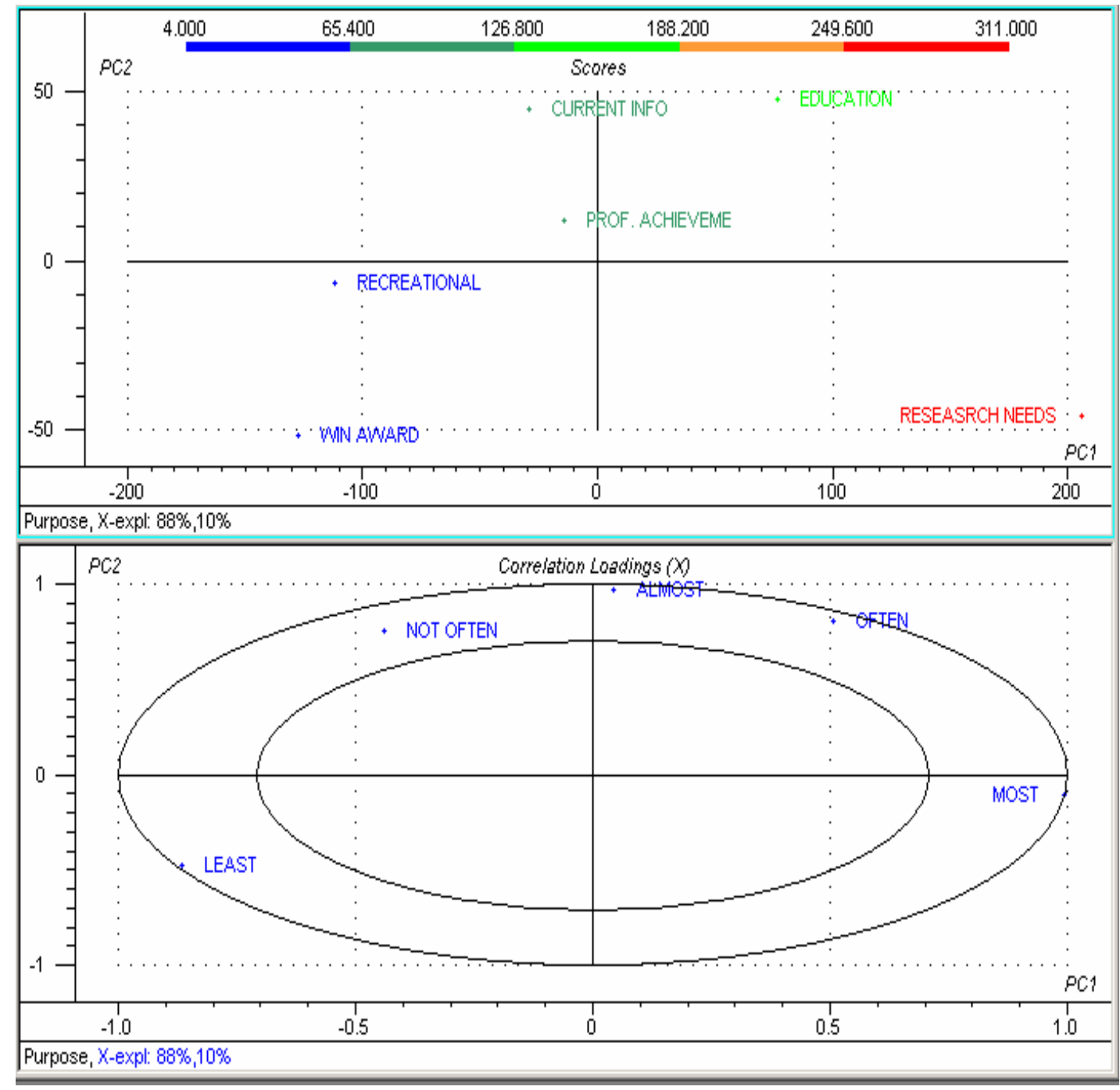

Figure 1: Purpose of Use of Electronic Journals

\section{Components of Electronic Journals}

The use of different aspects of the e-journals was evaluated. These were:

1. Table of Contents

2. Abstracts

3. Full Text

4. Article References

5. Alerting Services

The results of the PCA are given in Fig. 2 below. 


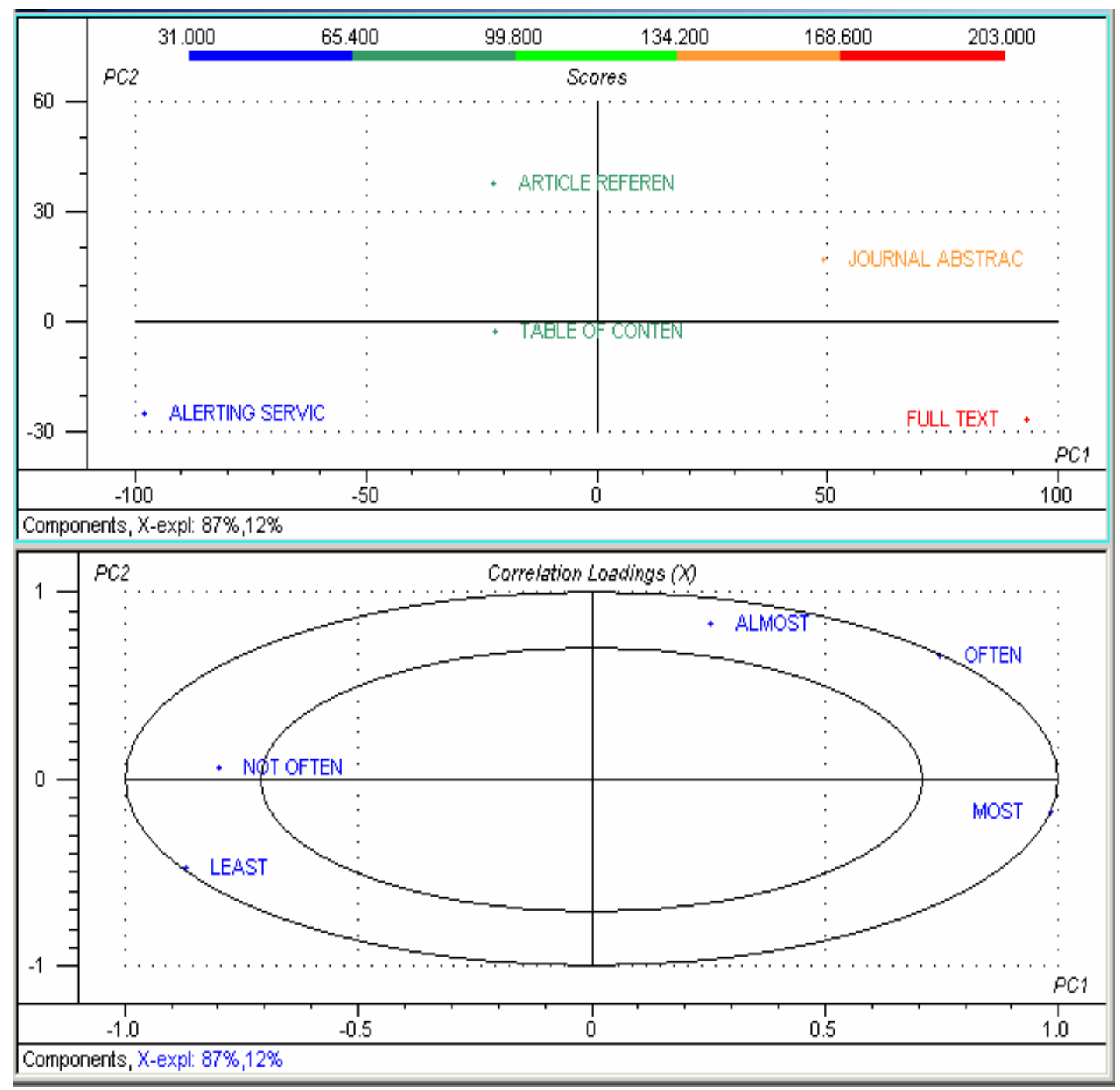

Figure 2: Preference of Components of Electronic Journals

The Score Plot and the Correlation Loading Plot of Fig.2 indicate that electronic journals are mostly used for accessing the 'Full Text' of research papers and often used for 'Journals Abstract', sometimes for 'Article References' and least for 'Alerting Services'.

\section{Preferred Format of Electronic Journals}

The format of electronic journals is considered to be one of the many parameters that affects their use. Figure 3 presents the Scores Plot and Correlation Loading Plot of the PCA on this data. 


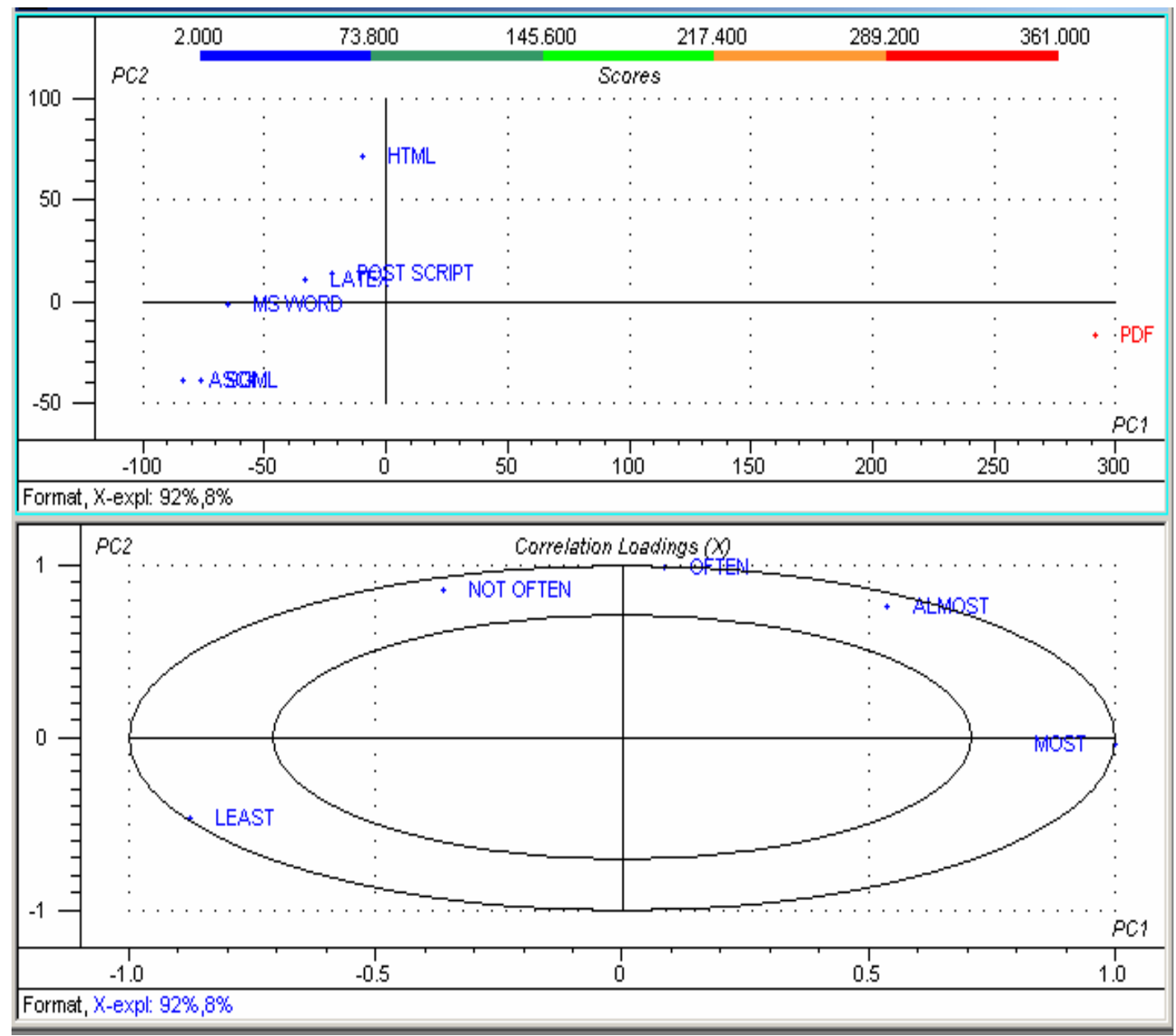

Figure 3: Preference of Format of Electronic Journals

Figure 3 shows that the PDF format is the 'most' and 'sometimes' preferred choice of electronic journal, the HTML format 'often' used, the MS Word, the LaTeX, the ASCII and PostScript formats are the 'least' desired formats. This maybe because most of the electronic journals were easily available in PDF or HTML.

It seems that PDF and HTML are the two most preferred formats with publishers; so users of electronic journals have to accept these two formats. In addition, reader software for PDF and browser software for HTML formats are free. When free software is available, generally users are not ready to pay money for other formats. PDF uses less computer memory and the look of the original article is maintained HTML is also platform independent and perhaps this is the reason of its preferences by users.

\section{Frequency of Use and Amount of Time Spent on Reading E-Journals}

The respondents were asked about frequency of use and the time they spent reading electronic journals. Table III shows the amount of time spent on online and off line 
reading of electronic journals and the frequency of their use (The numbers inside tables refer to the number of users).

\begin{tabular}{||c|c|c|c|c|c|c|c|c|c|}
\hline \multirow{2}{*}{ Use } & \multicolumn{4}{|c||}{ Time Spent on Online Reading } & \multicolumn{3}{|c|}{ Time Spent on Off Line } \\
Reading
\end{tabular}

Table III: The Frequency of Use and the Time Spent

$$
\chi^{2}=39.277 \quad \mathrm{df}=8 \quad \chi^{2}=26.456 \quad \mathrm{df}=6
$$

In order to test whether the amount of time spent on online/offline reading has any association with the frequency of using electronic journals, the $\chi^{2}$ test of independence was carried out. The results clearly showed that there is a significant association between the time spent on reading online/offline and frequency of use of electronic journals.

\section{Frequency of Use and the Number of Articles Read}

This study tested whether the number of articles read is also a function of frequency of use. Table IV shows the distribution of articles read over various usage frequencies.

\begin{tabular}{|l|c|c|c|}
\hline \multirow{2}{*}{ Frequency of Use } & \multicolumn{3}{|c|}{ Number of Articles Read } \\
\cline { 2 - 4 } & $<$-5 Articles & 5-10 Articles & $>$ 10 Articles \\
\hline Daily & 44 & 81 & 35 \\
\hline Biweekly & 39 & 20 & 5 \\
\hline Weekly & 90 & 36 & 7 \\
\hline
\end{tabular}

Table IV: The Frequency of Use and Number of Articles Read

$$
\chi^{2}=55.144 \quad \mathrm{df}=4
$$


The $\chi^{2}$ test carried out on Table IV reveals that there is an association between the number of articles read and the frequency of use of electronic journals. Those who use electronic journals daily tend to read more articles than those who use them biweekly and weekly.

\section{Status of Respondents and Frequency of Use}

The status of respondents might have an influence on the frequency of use and the data is summarized in Table V. The total answers are 343 not 397 because 54 respondents did not respond to this question.

\begin{tabular}{||c|l|c|c|c||}
\hline \multirow{2}{*}{ SN } & \multicolumn{2}{|c|}{ Status of Respondents } & \multicolumn{3}{c||}{ Frequency of Use } \\
\cline { 3 - 5 } & & Daily & Biweekly & Weekly \\
\hline 1 & Academic Staff & 07 & 02 & 01 \\
\hline 2 & Research Staff & 17 & 2 & 8 \\
\hline 3 & Research Students (M. Phil, Ph. D) & 96 & 33 & 59 \\
\hline 4 & Postgraduate Students (M.Sc, ME, M.B.A, MA) & 20 & 15 & 31 \\
\hline 5 & Guest Users & 15 & 11 & 26 \\
\hline & & $\mathbf{1 5 5}$ & $\mathbf{6 3}$ & $\mathbf{1 2 5}$ \\
\hline
\end{tabular}

Table V: Status of Respondents and Frequency of Use

$$
\chi^{2}=19.52 \quad \mathrm{P}<0.05 \text { (It is Significant) }
$$

To see if there was indeed an association between frequency of use and status of respondents, the $\chi^{2}$ test was carried out on Table $\mathrm{V}$. The result showed that there is a significant association between the frequency of use and the status of respondents. It means research staff, research and postgraduate students are using electronic journals daily but not academic staff and guest users. This may be because research staff, research and postgraduate students are involved in research every day so they need to be up to date with currently published material. It seems that 'providing up to date information' is the most attractive feature of electronic journals for users at IISc. The low usage of electronic journals by academic staff has already been reported in the literature (Lenares, 1999; Bonthron, 2002).

\section{Importance of Electronic Journals and Their Use by Respondents}

The following question was asked: "Do you agree with this statement 'Online/electronic journals are one of the most important parts of scientific communication?”. Table VI shows the results 


\begin{tabular}{|c|c|c|}
\hline \multirow{2}{*}{ Importance of E-J } & \multicolumn{2}{|c|}{ Use of Electronic Journals } \\
\cline { 2 - 3 } & Yes & No \\
\hline Yes & $362(98.1 \%)$ & $3(0.81 \%)$ \\
\hline No & $4(1.08 \%)$ & $0(0.00 \%)$ \\
\hline
\end{tabular}

Table VI: Importance of E-journals and Use

Of 397 respondents, 366 (92.19 percent) of them responded positively. The result demonstrates the strong and predominant role of electronic journals in scientific communication. Table VI shows that 98.1 percent of those who use electronic journals which strongly underlines the conclusion that "Online/electronic journals are one of the most important parts of scientific communication.”

\section{Monitor versus Print out Reading}

The users were also asked about reading on a monitor compared to reading a print out. Table VII and Fig 4 show the results

\begin{tabular}{||l|c|c|c|c|c|}
\hline Types of Reading & $\begin{array}{c}\text { Always } \\
\mathbf{( \% )}\end{array}$ & $\begin{array}{c}\text { Often } \\
\mathbf{( \% )}\end{array}$ & $\begin{array}{c}\text { Usually } \\
\mathbf{( \% )}\end{array}$ & $\begin{array}{c}\text { Sometimes } \\
\mathbf{( \% )}\end{array}$ & $\begin{array}{c}\text { Never } \\
\mathbf{( \% )}\end{array}$ \\
\hline Read on Monitor & 83 & 88 & 66 & 84 & 7 \\
$(25.30)$ & $(26.82)$ & $(20.12)$ & $(25.6)$ & $(2.13)$ \\
\hline Read Print Out & 90 & 90 & 31 & 111 & 13 \\
$(26.86)$ & $(26.86)$ & $(9.25)$ & $(33.13)$ & $(3.88)$ \\
\hline
\end{tabular}

Table VII: Monitor versus Print out Reading

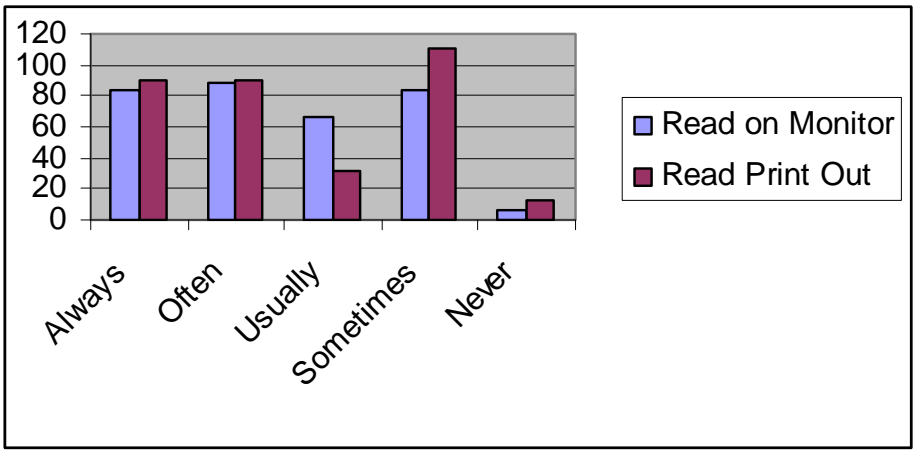

Figure 4: Monitor versus Print out Reading 
As it is seen in Figure 4, the preference from respondents is almost equally distributed. 25.3 percent of respondents always read on the monitor and 26.8 percent always read print out. Also, 26.8 percent often read on the monitor while 26.8 percent of respondents often read print out. These percentages suggest that there is an even balance between the media preference. However, a surprisingly high number were happy to read on screen.

\section{Accessibility and Availability of Electronic Journals}

The respondents were asked to rank the accessibility and availability of electronic journals on a four-point scale (see questionnaire at appendix 1). PCA was carried out on this data to identify the classification of availability and accessibility with respect to the scaling. Figure 5 gives the Scores Plot and Correlation Loading Plot of the PCA.

Figure 5: Accessibility and Availability of Electronic Journals

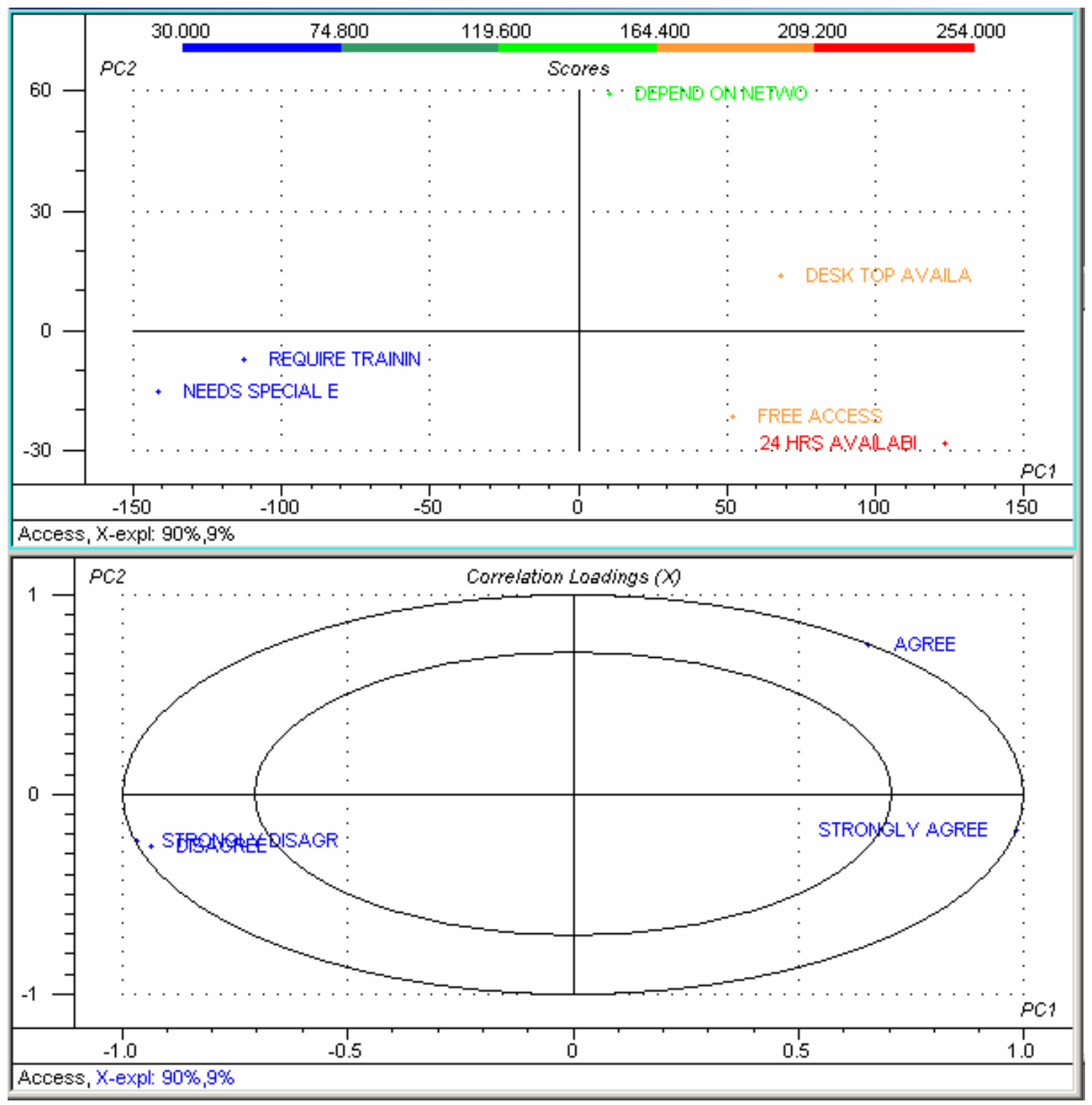


From Figure 5 it is seen that the respondents strongly agreed that electronic journals were 'available 24 hours', they had 'free access' and they also had 'desktop availability'. They also agreed that the availability of electronic journals 'depend on the network'. They strongly disagreed that they 'need special equipment and training'.

It seems that one of the most appealing features of electronic journals is availability at anytime. The majority of users agreed that electronic journals are available at IISc at anytime, free of charge.

\section{General Features of Electronic Journals}

The respondents were asked to scale the general feature of electronic journals on a four-point scale. PCA was carried out to see the classification of these features with respect to the opinion of the respondents. Figure 6 gives the Score Plot and Correlation Loading Plot from which it is easy to identify the classification.

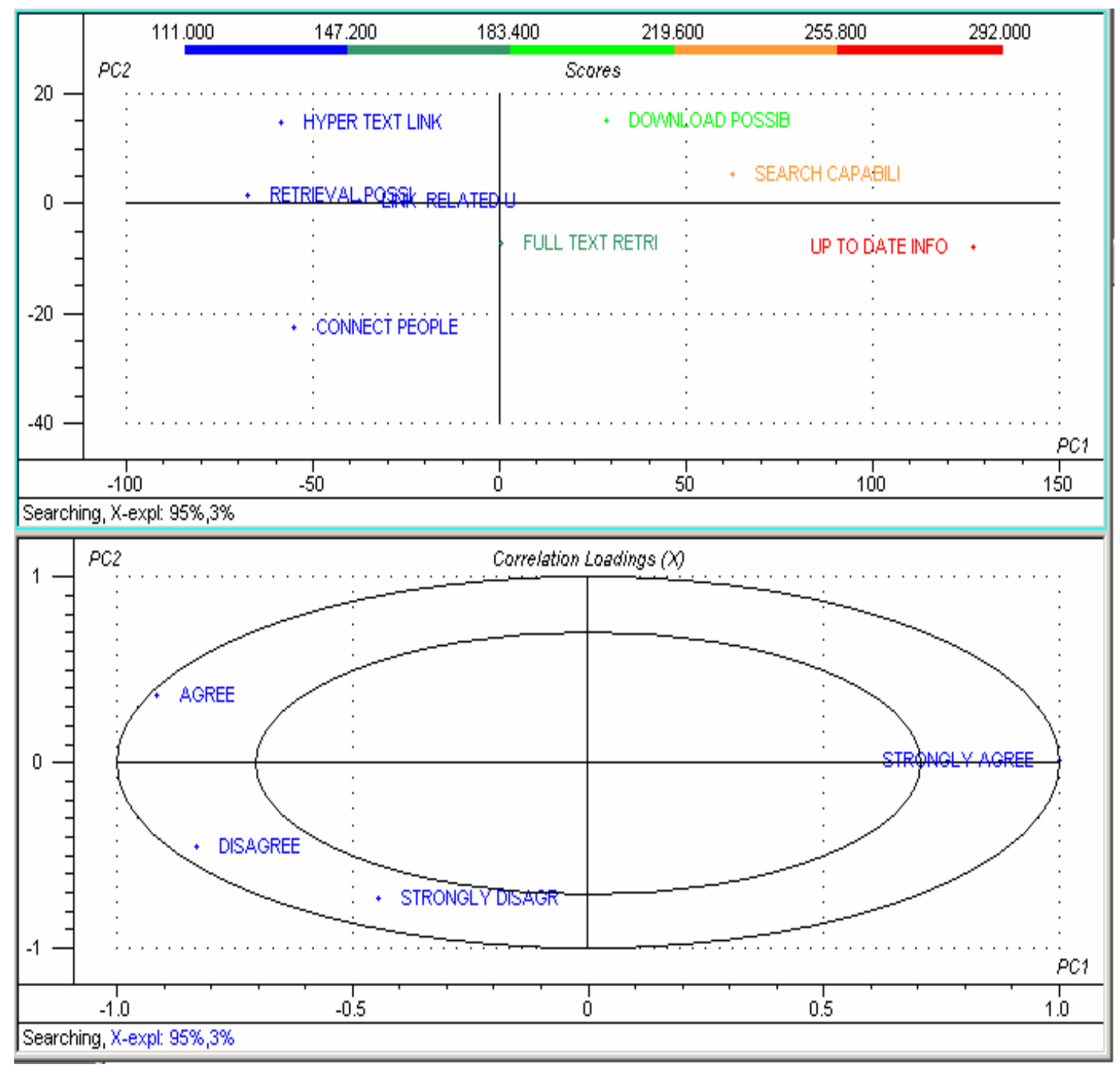

Figure 6: General Features of Electronic Journals 
It is seen from Figure 6 that the respondents 'strongly agree' that the advantages of e journals are the 'up to date information', 'search capabilities' and 'download possibilities'; they 'agree' with 'hypertext links' and 'retrieval possibilities'. It seems that the most interesting general feature of electronic journals for users at IISc is to 'provide up to date information' and this feature leads users toward using electronic journals. This result confirms the results of earlier study in Max Planck Society (Rusch-Feja \& Siebeky, 1999).

\section{Top Used Journals}

The respondents were also asked to list the titles of journals that they use regularly. Based on the titles listed by them, Nature, Science and PNAS (Proceeding National Academic Sciences) are the most popular research journals. Further analysis on these top thirty journals was carried out by the author and published in Libri (Galyani M., 2006).

\section{Discussion and Conclusion}

The results of the survey reflect a growing interest in electronic journals among the users at the IISc. The same results had reported in the literature (e.g., Rusch-Feja, \& Siebeky, 1999; Lenares, 1999; Pazur, 2002; Colvin, 2004). The literature review presented in this paper mostly refers to researches which are carried out in the West. The current study confirms those results by saying that electronic journals are well accepted in a developing country such as India when they are made available to the users.

Study of publishers showed that while Elsevier electronic journals (63.9 percent) are most popular among users of IISc; the Sage Publication electronic journals ranked lowest (2.51 percent) in their popularity. The other publishers in decreasing order of popularity were:

- John Wily \& Sons (38.0 percent);

- $\quad$ Springer-Verlag (34.7 percent );

- IEEE (29.97 percent );

- American Chemical Society (23.4 percent ); and

- Cambridge University Press (16.8 percent ).

This high use of Elsevier journals has already been reported in Obst's study in 2003 and Rusch-Feja, \& Siebeky's study in 1999. Convenience and accessibility are the two most important issues considered by users in using electronic journals of a particular publisher; perhaps these are the reason of low usage of the Sage Publications at this institute. As mentioned earlier, one possible reason of Elsevier's domination is their high number of scientific journals; merging with Academic Press in 2003 increased its number of electronic journals still further; even at the time of publishing this paper more mergers with other publishers are being proposed. While the business of publishing scholarly journals is already dominated by the US and Europe-based publishers, these mergers concentrate even more power in fewer hands in scientific publishing. In the other study by this author a comparison was made between for-profit/commercial publishers and non-for-profit publishers by the price of electronic journals and interesting results were found (Galyani M., 2007). More usage study of electronic journal by publishers (especially among different disciplines) would be beneficial to librarians. 
Although Elsevier is the most used publisher at IISc, further analysis of the top thirty used journals at IISc showed that two-thirds belong to non-profit/society publishers and one-third to for-profit/commercial publishers (Galyani M., 2007).

Electronic journals are mostly used for 'Research needs' followed by 'Education', 'Current facts and services'. As expected they are least used for 'Recreational purpose' and 'Winning awards'. This result confirms the results of Tenopir and King's study in 2004. The results of the present study also clearly showed that there is a significant association between the time spent on reading online/offline and frequency of use of electronic journals. This result confirms the results of a recent study by King, Tenopir and Clarke in 2006. They found that readers who take the time to download articles are more likely to read most of the text than only part of it (King, Tenopir \& Clarke, 2006). As mentioned in the review section, the pattern of reading by users is changing in the digital environment toward less concentrated reading but average amount of reading is increasing. A study by King and others in 2003 reveals that twenty-five year trends of reading by university scientists show substantial increases in average amount of reading. Scientists appear to be more advanced in their use of electronic journals than other faculty, but changes are taking place within all faculty disciplines (King, et. al., 2003).

This study has shown that PDF format is the most preferred choice of electronic journal. The HTML format, MS Word, LaTeX, ASCII and PostScript formats are next in that order of preference. It may be noted here that PDF and HTML formats are the most common formats in which the full texts are available. It appears that users were also accepting these formats as their choices.

The study of the media preference (reading on the monitor/reading print out) suggests that there is an even balance between the media preference. Earlier studies found that users prefer to read print out than read on the monitor (e.g., Woodward, 1998; Rusch-Feja, \& Siebeky, 1999; Brown, 1999; Pazur, 2002). The result of the present study shows some changes in this trend. This result confirms more recent studies such as Liu's study in 2005. His study shows that a screen-based reading behavior is emerging for reading electronic documents. The screen-based reading behavior is characterized by more time spent on browsing and scanning, keyword spotting, one-time reading, non-linear reading, and reading more selectively, while less time is spent on in-depth reading, and concentrated reading (Liu, 2005); this screen-based reading behavior seems also to be happening at the IISc .

The fact that users have free access to electronic journals at any time from their own computers seems to be the most appealing feature. The same result was reported at Clajus and Maier study in 2001 and Rusch-Feja, \& Siebeky in 1999. Clajus and Maier had reported that the biggest advantage of the new service was full-text access from users own desktop (49 percent), and the fact that the electronic journal is available before the print version.

Pazur's study had also revealed that the RBI respondents (Rudjer Boskovic Institute in Zagreb) stressed the availability before the print version as the most important advantage of electronic journals. The fact that the electronic journal is available before the print, is an important advantage of electronic journals in developing countries such as India. Considering the fact that the leading publishers of scholarly electronic journals are located in the U.S and Europe, and the print version of electronic journal arrives late in India, this feature of electronic journals became very attractive for users at IISc. It may be noted here there are a large number of 
electronic journals made available through consortia at the present. India is active in consortia activities and is providing access to electronic journals through consortia especially for research institutions including IISc.

In addition, it is found from this study that the journals Nature, Science and PNAS (Proceeding National Academic Sciences) are the most popular research journals. This result is close to a similar study in Germany in 1999 (Rusch-Feja, \& Siebeky, 1999). There are many similarities between these two studies, so a comparison was made between the results in a separate paper (Galyani M., 2006).

The result of this study in general suggests that the library network with the availability of significant numbers of electronic journals at the IISc has been successful. The results suggest that 24 hours free access to electronic resources at the users' desktop leads to increased acceptance and use of scholarly electronic journals. This service need to be maintained and continued in future at IISc. This successful service can be used as a model for other institutions in India as well as other developing countries.

Acknowledgement: The authors express their sincere thanks to Dr. SHALINI R. URS, Professor Dept. of Library and Information Science, University of Mysore, Mysore, INDIA for her valuable suggestions.

\section{References}

Baldwin, C. and D. Pullinger. 2000. What Readers Value in Academic Journals. Learned Publishing, 13(4): 229-239.

Bonthron, K.A. 2002. Usage of Electronic Journals by Academics: A Case Study. MSc dissertation. Aberystwyth: University of Wales Aberystwyth.

Bonthron, Karen. et al. 2003. Trends in Use of Electronic Journals in Higher Education in the UK - Views of Academic Staff and Students. D-Lib Magazine (June): 9(6). URL: http://www.dlib.org/dlib/June03/authors/06authors.html\#BONTHRON [Viewed August 12, 2004]

Brown, C. M. 1999. Information Seeking Behavior of Scientists in the Electronic Information Age: Astronomers, Chemists, Mathematicians, and Physicists. Journal of the American Society for Information Science, 50(10): 929-943.

Clajus, G. and C. Maier. 2001. Elektronische Zeitschriften and der UB: Eine Untersuchung zum Nutzerverhalten. URL: http://www.unikoeln.de/rrzk/kompass/90/k9012.html [Viewed December 12, 2003]

Colvin, John and Judith Keene. 2004. Supporting Undergraduate Learning through the Collaborative Promotion of E-Journals by Library and Academic Departments. Information Research (January): 9(2). 
De Groote, Sandra L. and Dorsch, Josephine L. 2001. Online Journals: Impact on Print Journal Usage. Journal of the Medical Library Association (October), 89(4): 372-378.

De Groote, Sandra L. and Dorsch, Josephine L. 2003. Measuring Use Patterns of Online Journals and Databases. Journal of the Medical Library Association (April), 91(2): 231-241.

Diedrichs, C. P. 2001. E-Journals: The OhioLINK Experience. Library Collections, Acquisitions, and Technical Services, 25: 191-210.

E-Journal Usage Study and Scholarly Practice: An Ethnographic Perspective on the Role and Impact of E-Journal Usage Among Users of Biomedical Literature: Stanford E-Journal User Study. 2001. URL: http://www.slac.stanford.edu/library/ssrl/journal/ [Viewed July 20, 2003]

Electronic Journals Survey. $2000 . \quad$ URL: http://www.bath.ac.uk/library/about/general/surveys/2000/ [Viewed July 12, 2003]

Galyani Moghaddam, G. 2006. Price and Value of Electronic Journals: A Survey at the Indian Institute of Science. Libri: International Journal of Libraries and Information Services (June), 56(2): 108-116.

Galyani Moghaddam, G. 2007. Scholarly Electronic Journal Publishing: A Study Comparing Commercial and Nonprofit/University Publishers. The Serials Librarian, 51 (3/4): 165-183.

Gargiulo, Paola. [et. al] .2003. Digital Libraries and Users: an Italian Experience. The paper was presented at the Toward a User-Centered Approach to Digital Libraries, (September 8 - 9, 2003) Espoo, Finland.

Holmquist, J. E. 1997. Survey on the Use of Electronic Journals at Princeton. URL: http://www.eso.org/gen-fac/libraries/lisa3/holmquistj.html [Viewed May 15, 2003]

Huntington, P., Nicholas, D., Jamali, H. R. and Tenopir, C. 2006. Article Decay in the Digital Environment: An Analysis of Usage of OhioLINK by Date of Publication, Employing Deep Log Methods. Journal of the American Society for Information Science and Technology, 57(13): 1840-1851.

King, D.W., Tenopir, C., Montgomery, C.H. and Aerni, S.E. 2003. Patterns of Journal Use by Faculty at Three Diverse Universities. D-Lib Magazine (October), 9(10). URL: http://www.dlib.org/dlib/october03/authors/10authors.html\#KING [Viewed December 16, 2006]

King, D.W., Tenopir, C., and Clarke, M. 2006. Measuring Total Reading of Journal Articles. D-Lib Magazine (October), 12(10). URL: 
http://www.dlib.org/dlib/october06/authors/10authors.html\#KING

December 20, 2006]

[Viewed

Lenares, Deborah. 1999. Faculty Use of Electronic Journals at Research Institutions. The paper was presented at Racing Toward Tomorrow, ACRL Ninth National Conference, April 8-11, 1999, Detroit, Michigan. URL: http://www.ala.org/acrl/lenares.pdf [Viewed August 16, 2003]

Liu, Ziming. 2005. Reading Behavior in the Digital Environment: Changes in Reading Behavior Over the Past Ten Years. Journal of Documentation 61(6): 700712.

Morse, D. H. and W. A. Clintworth. 2000. Comparing Patterns of Print and Electronic Journals Use in a Health Science Library. Science and Technology Librarianship (Fall).

Nicholas, D., Huntington, P., Dobrowolski, T., Rowlands, I., Jamali, H.R., and Polydoratou, P. 2005. Revisiting "Obsolescence" and Journal Article "Decay" through Usage Data: An Analysis of Digital Journal Use by Year of Publication. Information Processing and Management 41(6): 1441-1461.

Obst, Oliver. 2003. Patterns and Costs of Printed and Online Journal Usage. Health Information and Libraries Journal (March), 20(1): 22-32.

Odlyzko, A.M. 2000. The Rapid Evolution of Scholarly Communication. Conference on the Economics and Usage of Digital Library Collections, March 2324, 2000. URL: http://www.si.umich.edu/PEAK-2000/odlyzko.pdf [Viewed December 15, 2006]

Pazur, Ivana. 2002. The Use and the Attitude of Scientists from the Rudjer Boskovic Institute about Electronic Journals: A User Study. URL: http://knjiznica.irb.hr/eng/anketa/electrocas.html [Viewed September 6, 2003]

Rusch-Feja, Diann, and Uta Siebeky. 1999. Evaluation of Usage and Acceptance of Electronic Journals: Results of an Electronic Survey of Max Planck Society Researchers including Usage Statistics from Elsevier, Springer, and Academic Press (full report). D-Lib Magazine (October), 5(10). URL: http://www.dlib.org/dlib/october99/rusch-feja/10rusch-feja-full-report.html [Viewed August 19, 2006]

Smith, Lindsey. 2002. A Tutorial on Principal Components Analysis. URL: http://www.cs.otago.ac.nz/cosc453/student_tutorials/principal_components.pdf

[Viewed December 19, 2004]

Tenopir, Carol .2005. Inundated with Data. (September). URL: http://www.libraryjournal.com [Viewed December 12, 2006] 
Tenopir, C., and D.W. King. 2000. Towards Electronic Journals: Realities for Scientists, Librarians, and Publishers. Washington, D.C.: Special Libraries Association.

Tenopir, C. and D.W. King. 2002. Reading Behavior and Electronic Journals. Learned Publishing (October), 15(4).

Tenopir, C., King, D.W., and Amy Bush. 2004. Medical Faculty’s Use of Print and Electronic Journals: Changes over Time and in Comparison with Scientists. Journal of the Medical Library Association (April), 92(2): 233-241.

Wiley, L. and T. E. Chrzastowski. 2002. The Illinois Interlibrary Loan Assessment Project II: Revisiting Statewide Article Sharing and Assessing the Impact of Electronic Full-text Journals. Library Collections, Acquisitions, and Technical Services 26(1): 19-33.

Woodward, H. [et al]. 1998. Café Just: An Electronic Journals User Survey. URL: http://jodi.esc.soton.ac.uk/Articles/v01/i03/Woodward/ [Viewed September 14, 2003] 


\section{QUESTIONNAIRE}

\section{BACKGROUND INFORMATION}

Name:

Sex: Female ( )

Department:

Male ( )

Status: (Tick One) （ ) Academic staff

( ) Research staff

( ) Research students (Mphil, PhD, M.Sc, ME, MBA, MA)

( ) Other (please specify)

1. Are you aware of the availability of electronic/online journals at your institute?

$$
\operatorname{Yes}(\quad \text { No }(\text { ) }
$$

2. Do you use electronic/online journals? Yes $($ ) No $($ )

If yes, please indicate from which publishers (Tick as many as applicable).

If the publisher is not included below please mention it.

\begin{tabular}{|c|c|}
\hline ACM Press (Am. Com. Machin) & $\begin{array}{l}\text { Kluwer Academic } \\
\text { Publishing }\end{array}$ \\
\hline American Chemical Society & $\begin{array}{l}\text { IEEE (Insof Electrical \& } \\
\text { Elec.) }\end{array}$ \\
\hline AIP (American Insof Physics) & IOP (UK) (Insof Physics) \\
\hline Am. Society for Microbiology & $\begin{array}{l}\text { ASBMB (Am. Soc. for } \\
\text { Biochemistry \& Molecular } \\
\text { Biology) }\end{array}$ \\
\hline APS (American Physical Soci.) & MCB Uni. Press (Emerald) \\
\hline ASCE (Am. Socof Civil Eng.) & MIT Press \\
\hline Blackwell Publishing & Oxford University Press \\
\hline Cambridge University Press & Sage Publications \\
\hline Elsevier (Inc. Academic Press ) & Springer - Verlag \\
\hline John Wiley \& Sons, Inc & Taylor \& Francis, Ltd. \\
\hline
\end{tabular}

3. Mention which type of subscription you are using.
Personal Subscription ( )
Library-based Subscription ( ) 
4. List the titles of electronic/online journals that you use?

1.

2.

3.

4.

5.

5. For what purposes do you use electronic/online journals?

\begin{tabular}{|l|l|l|l|l|l|}
\hline Purpose of Use & Most & Often & Sometimes & Somewhat & Least \\
\hline Research Needs & & & & & \\
\hline Education & & & & & \\
\hline $\begin{array}{l}\text { Professional } \\
\text { Achievement }\end{array}$ & & & & & \\
\hline Recreational & & & & & \\
\hline Win Award & & & & & \\
\hline $\begin{array}{l}\text { Current } \\
\text { Information }\end{array}$ & & & & & \\
\hline
\end{tabular}

6. Which format of electronic/online journals do you use?

\begin{tabular}{|l|l|l|l|l|l|}
\hline Type of Format & Most & Often & Sometimes & Somewhat & Least \\
\hline PDF & & & & & \\
\hline HTML & & & & & \\
\hline SGML & & & & & \\
\hline ASCII & & & & & \\
\hline MS Word & & & & & \\
\hline PostScript & & & & & \\
\hline LaTex & & & & & \\
\hline
\end{tabular}


7. Which component of electronic/online journals do you use?

\begin{tabular}{|l|l|l|l|l|l|}
\hline $\begin{array}{c}\text { Component of Online } \\
\text { Journals }\end{array}$ & Most & Often & Sometimes & Somewhat & Least \\
\hline Table of Contents & & & & & \\
\hline Journal Abstracts & & & & & \\
\hline Full Text & & & & & \\
\hline Article References & & & & & \\
\hline Alerting Services & & & & & \\
\hline
\end{tabular}

8. On average how often do you access online journals?

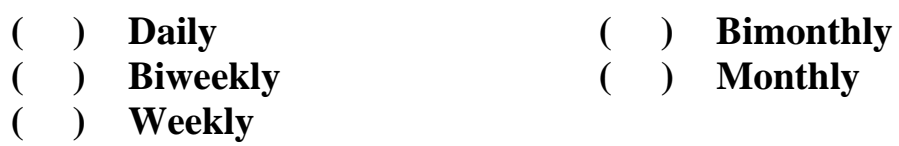

9. On average how long does it take to access or download online articles?
( ) Less than $10 \mathrm{~min}$.
( ) $30-40 \mathrm{~min}$.
( ) $10-20 \mathrm{~min}$.
( ) $40-50$ min.
( ) $20-30 \mathrm{~min}$.
( ) More than $50 \mathrm{~min}$.

10. On average how much time do you spend weekly on reading online journals? (Please tick appropriate box).

\begin{tabular}{|l|l||l|l|}
\hline \multicolumn{2}{|c||}{ Online reading } & \multicolumn{2}{|c|}{$\begin{array}{c}\text { Off Line } \\
\text { Reading }\end{array}$} \\
\hline Up to 30 minutes & & Up to 60 min. & \\
\hline $30-60$ min. & & $60-120$ min. & \\
\hline $60-90$ min. & & $120-180$ min. & \\
\hline $90-120$ min. & & Above 180 mi & \\
\hline More than 120mi & & & \\
\hline
\end{tabular}


11. How many articles do you read in a week?

$\begin{array}{lll}\text { ( ) Less than } 5 & \text { ( ) } & 10-15 \\ \text { ( ) } 5-10 & \text { ( ) } & \text { More than } 15\end{array}$

12. How do you read online journals?

\begin{tabular}{|l|l|l|l|l|l|}
\hline Types & Always & Often & Usually & Sometimes & Never \\
\hline Read on a Monitor & & & & & \\
\hline Read Print out & & & & & \\
\hline
\end{tabular}

13. The following statements are about the accessibility and availability of electronic /online journals. Please Indicate how strongly you agree or disagree with each statement.

\begin{tabular}{|l|l|l|l|l|}
\hline \multicolumn{4}{|c|}{ Online Journals Accessibility and Availability } \\
\hline Statement & $\begin{array}{c}\text { Agree } \\
\text { Strongly }\end{array}$ & $\begin{array}{c}\text { Agree } \\
\text { Somewhat }\end{array}$ & $\begin{array}{c}\text { Disagree } \\
\text { Somewhat }\end{array}$ & $\begin{array}{c}\text { Disagree } \\
\text { Strongly }\end{array}$ \\
\hline $\begin{array}{l}24 \\
\text { Available HRS }\end{array}$ & & & & \\
\hline $\begin{array}{l}\text { Desktop } \\
\text { Availability }\end{array}$ & & & & \\
\hline $\begin{array}{l}\text { Free Access } \\
\text { Depend on } \\
\text { Network }\end{array}$ & & & & \\
\hline $\begin{array}{l}\text { Needs Special } \\
\text { Equipment }\end{array}$ & & & & \\
\hline $\begin{array}{l}\text { Require } \\
\text { Training }\end{array}$ & & & & \\
\hline
\end{tabular}


14. The following statements are about electronic/online journals general features. Please indicate how strongly you agree or disagree with each statement.

\begin{tabular}{|l|l|l|l|l|}
\hline \multicolumn{5}{|c|}{ Online Journals General Features } \\
\hline Statement & $\begin{array}{c}\text { Agree } \\
\text { Strongly }\end{array}$ & $\begin{array}{c}\text { Agree } \\
\text { Somewhat }\end{array}$ & $\begin{array}{c}\text { Disagree } \\
\text { Somewhat }\end{array}$ & $\begin{array}{c}\text { Disagree } \\
\text { Strongly }\end{array}$ \\
\hline $\begin{array}{l}\text { Up-to-date } \\
\text { Information }\end{array}$ & & & & \\
\hline $\begin{array}{l}\text { Search } \\
\text { Capabilities }\end{array}$ & & & & \\
\hline $\begin{array}{l}\text { Download } \\
\text { Possibilities }\end{array}$ & & & & \\
\hline $\begin{array}{l}\text { Full Text } \\
\text { Retrieval }\end{array}$ & & & & \\
\hline $\begin{array}{l}\text { Retrieval } \\
\text { Possibilities }\end{array}$ & & & & \\
\hline Hypertext Links & & & & \\
\hline $\begin{array}{l}\text { Link to Related } \\
\text { Items }\end{array}$ & & & & \\
\hline Connect People & & & & \\
\hline
\end{tabular}

15. How strongly do you agree or disagree with the following statements which describe electronic/online journal browsing features?

\begin{tabular}{|c|c|c|c|c|}
\hline \multicolumn{5}{|c|}{ Online Journals Browsing Features } \\
\hline Statement & $\begin{array}{c}\text { Agree } \\
\text { Strongly }\end{array}$ & $\begin{array}{c}\text { Agree } \\
\text { Somewhat }\end{array}$ & $\begin{array}{c}\text { Disagree } \\
\text { Somewhat }\end{array}$ & $\begin{array}{l}\text { Disagree } \\
\text { Strongly }\end{array}$ \\
\hline \multicolumn{5}{|l|}{$\begin{array}{l}\text { Contain } \\
\text { Multimedia } \\
\text { Information }\end{array}$} \\
\hline \multicolumn{5}{|c|}{$\begin{array}{l}\text { Contents Easy to } \\
\text { Understand }\end{array}$} \\
\hline \multicolumn{5}{|l|}{$\begin{array}{l}\text { User-Friendly } \\
\text { Interface }\end{array}$} \\
\hline \multicolumn{5}{|c|}{$\begin{array}{ll}\text { Reading on } \\
\text { Monitor }\end{array}$} \\
\hline \multicolumn{5}{|l|}{$\begin{array}{l}\text { Lack of } \\
\text { Standardized } \\
\text { Formats } \\
\end{array}$} \\
\hline $\begin{array}{l}\text { Poor Graphic } \\
\text { Quality }\end{array}$ & & & & \\
\hline
\end{tabular}


16. Do you agree with this statement "Online/Electronic journals are one of the most important parts of scientific communication?

Yes $\quad(\quad$ No $\quad(\quad)$

Thank you very much for your cooperation in completing this questionnaire. I would like to remind you once again to please return it to the office at your Department. If you have any additional remarks about your ejournal usage, or comments on the questionnaire, please write here. 